palgrave advances in modern military history 
Palgrave Advances

Titles include:

Richard Whatmore and Brian Young (editors)

INTELLECTUAL HISTORY

Saki R. Dockrill and Geraint A. Hughes (editors)

COLD WAR HISTORY

H.G. Cocks and Matt Houlbrook (editors)

THE MODERN HISTORY OF SEXUALITY

Patrick Finney (editor)

INTERNATIONAL HISTORY

Jonathan Harris (editor)

BYZANTINE HISTORY

Marnie Hughes-Warrington (editor) WORLD HISTORIES

Helen J. Nicholson (editor)

THE CRUSADES

Alec Ryrie (editor)

EUROPEAN REFORMATIONS

Jonathan Woolfson (editor)

RENAISSANCE HISTORIOGRAPHY

Matthew Hughes and William J. Philpott (editors)

MODERN MILITARY HISTORY

Forthcoming:

Jonathan Barry and Owen Davies (editors)

WITCHCRAFT HISTORIOGRAPHY

Katherine O'Donnell, Leann Lane

and Mary McAuliffe (editors)

IRISH HISTORY 


\title{
palgrave advances in modern military history
}

\author{
edited by \\ matthew hughes \\ brunel university \\ and \\ william i. philpott \\ king's college london
}


Editorial matter, selection, introduction (c) Matthew Hughes and William J. Philpott 2006 Ch. 1 (c) Laurent Henninger 2006; Ch. 2 (c) Alan James 2006; Ch. 3 (c) Michael Neiberg 2006; Ch. 4 (c) Nikolas Gardner 2006; Ch. 5 @ Warren Chin 2006;

Ch. 6 (c) John P. Cann 2006; Ch. 7 (c) William J. Philpott 2006; Ch. 8 @ John Buckley 2006; Ch. 9 (c) Andrew Lambert 2006; Ch. 10 @ Bruce Vandervort 2006; Ch. 11 (c) Peter Stanley 2006; Ch. 12 (c) Matthew Hughes 2006; Ch. 13 (c) Joanna Bourke 2006

Softcover reprint of the hardcover 1st edition 2006 978-1-4039-1767-6

All rights reserved. No reproduction, copy or transmission of this publication may be made without written permission.

No paragraph of this publication may be reproduced, copied or transmitted save with written permission or in accordance with the provisions of the Copyright, Designs and Patents Act 1988, or under the terms of any licence permitting limited copying issued by the Copyright Licensing Agency, 90 Tottenham Court Road, London W1T 4LP.

Any person who does any unauthorised act in relation to this publication may be liable to criminal prosecution and civil claims for damages.

The authors have asserted their rights to be identified as the authors of this work in accordance with the Copyright, Designs and Patents Act 1988.

First published 2006 by

PALGRAVE MACMILLAN

Houndmills, Basingstoke, Hampshire RG21 6XS and

175 Fifth Avenue, New York, N.Y. 10010

Companies and representatives throughout the world

PALGRAVE MACMILLAN is the global academic imprint of the Palgrave

Macmillan division of St Martin's Press LLC and of Palgrave Macmillan Ltd.

Macmillan ${ }^{\circledR}$ is a registered trademark in the United States,

United Kingdom and other countries. Palgrave is a registered

trademark in the European Union and other countries.

\section{ISBN 978-1-4039-1768-3 ISBN 978-0-230-62537-2 (eBook) DOI $10.1057 / 9780230625372$}

This book is printed on paper suitable for recycling and made from fully managed and sustained forest sources.

A catalogue record for this book is available from the British Library.

Library of Congress Cataloging-in-Publication Data

Palgrave advances in modern military history / [edited by] Matthew Hughes and William J. Philpott.

p. cm. - (Palgrave advances)

Includes bibliographical references and index.

1. Military art and science-History. 2. Naval art and science-History. 3. Military history, Modern. 4. Naval history, Modern. I. Hughes, Matthew, 1965- II. Philpott, William James. III. Series. 
notes on contributors vii

introduction 1

matthew hughes and william j. philpott

1. military revolutions and military history $\mathbf{8}$ laurent henninger

2. warfare and the rise of the state 23

alan james

3. war and society 42

michael s. neiberg

4. military thought from machiavelli to liddell hart 61 nikolas gardner

5. land warfare from machiavelli to desert storm $\mathbf{8 4}$ warren chin

6. low-intensity conflict, insurgency, terrorism and revolutionary war $\mathbf{1 0 7}$ john p. cann

7. total war 131 william $j$. philpott

8. air power 153 john buckley

9. naval warfare $\mathbf{1 7 2}$ andrew lambert 
10. war in the non-european world $\mathbf{1 9 5}$ bruce vandervort

11. imperial military history $\mathbf{2 1 4}$ peter stanley

12. technology, science and war 231 matthew hughes

13. new military history 258 joanna bourke

index 281 


\section{notes on contributors}

Joanna Bourke is Professor of History at Birkbeck College, University of London. She has published seven books, on Irish history, gender and 'the body', the history of psychological thought and modern warfare. Her books have been translated into Chinese, Italian, Portuguese, Spanish, Catalan and Turkish. An Intimate History of Killing: Face-to-Face Killing in Twentieth Century Warfare (1998) won the Fraenkel Prize in Contemporary History for 1998 and the Wolfson History Prize for 2000. Her book entitled Fear: A Cultural History was published by Virago in 2005. She is currently writing a history of rapists in the nineteenth and twentieth centuries, to be published in late 2006.

John Buckley is Reader in Military History at the University of Wolverhampton. Dr Buckley has written widely on many aspects of military studies, particularly the inter-war years, the Second World War and air power. He is the author of The RAF and Trade Defence: Constant Endeavour (1995), Air Power in the Age of Total War (1999) and British Armour in the Normandy Campaign 1944 (2004).

John P. Cann is Professor of National Security Studies at the US Marine Corps Command and Staff College, Quantico, Virginia. Dr Cann earned his doctorate at King's College London in 1996, and is the author of Counterinsurgency in Africa: The Portuguese Way of War, 1961-1974 (1996). A retired naval captain and flight officer, he was awarded the Silver Medal of Dom Afonso Henriques for his studies on conflict in Lusophone Africa.

Warren Chin is Senior Lecturer in the Defence Studies Department at the Joint Services Command and Staff College and Academic Director of the British army's command and staff course. Dr Chin also teaches at the Royal College of Defence Studies and was a Lecturer in War Studies at the 
Royal Military Academy, Sandhurst. He specializes in British defence policy, weapons acquisition and the study of land warfare.

Nikolas Gardner teaches military history and theory at the University of Salford in Greater Manchester. Dr Gardner is the author of Trial by Fire: Command and the British Expeditionary Force in 1914 (2003), as well as articles in War \& Society, War in History and The Journal of Military History.

Laurent Henninger is chargé de mission at the Centre d'études d'histoire de la défense (based at Chateau de Vincennes, Paris), where he works on the philosophy and impact of 'military revolutions' over the longue durée, and runs a seminar on 'new battle history'.

Matthew Hughes is Senior Lecturer in History at Brunel University. His recent publications include Allenby in Palestine: The Middle East Correspondence of Field Marshal Viscount Allenby, June 1917-October 1919 (2004) and (with Gaynor Johnson) Fanaticism and Conflict in the Modern Age (2005). Dr Hughes is a Fellow of the Royal Historical Society and Honorary Editor of the Journal of the Society for Army Historical Research.

Alan James is Lecturer in the Department of War Studies at King's College London, and a member of the 'Laughton Naval History Unit'. Dr James is the author of The Navy and Government in Early Modern France, 1572-1661 (2004) and The Origins of French Absolutism (2006), along with a number of articles on naval, military, and confessional conflict in the sixteenth and seventeenth centuries.

Andrew Lambert is Laughton Professor of Naval History in the Department of War Studies at King's College London. A Fellow of the Royal Historical Society, his books include The Crimean War: British Grand Strategy against Russia 1853-1856 (1990), The Last Sailing Battlefleet: Maintaining Naval Mastery 1815-1850 (1991) and The Foundations of Naval History: John Knox Laughton, the Royal Navy and the Historical Profession (1998). His latest book, Nelson: Britannia's God of War was published in October 2004. He wrote and presented the three-part series 'War at Sea' for BBC2, broadcast in February 2004.

Michael S. Neiberg is Professor of History and Co-Director of the Center for the Study of War and Society at the University of Southern Mississippi. His recent publications include Fighting the Great War: A Global History (2005) and Warfare and Society in Europe: 1898 to the Present (2004).

William J. Philpott is Senior Lecturer in War Studies in the Department of War Studies, King's College London. Dr Philpott is the author of Anglo- 
French Relations and Strategy on the Western Front, 1914-1918 (1996) and coauthor (with Matthew Hughes) of The Palgrave Concise Atlas of the First World War (2005) and academic editor of the Palgrave monograph series Studies in Military and Strategic History.

Peter Stanley is Principal Historian at the Australian War Memorial, Canberra, where he has worked since 1980. Dr Stanley has published 18 books including The Remote Garrison: The British Army in Australia 1788-1870 (1986), White Mutiny: British Military Culture in India, 1825-1875 (1998) and For Fear of Pain: British Surgery 1790-1850 (2003).

Bruce Vandervort is Professor of Modern European and African History at the Virginia Military Institute in Lexington, Virginia, USA. He is the author of Wars of Imperial Conquest in Africa, 1830-1914 (1998) and serves as editor of The Journal of Military History. 